\title{
PENERAPAN MODEL PROBLEM BASED LEARNING UNTUK MENINGKATKAN KEMAMPUAN BERPIKIR KRITIS SISWA KELAS V SD
}

\author{
Dewi Nurkhasanah \\ dewinurkhasanah40@gmail.com \\ SD Negeri Noborejo 01 \\ Wahyudi \\ yudhi@staff.uksw.edu \\ Program Studi Pendidikan Sekolah Dasar \\ FKIP-Universitas Kristen Satya Wacana \\ Endang Indarini \\ eindarini@gmail.com \\ Program Studi Pendidikan Sekolah Dasar \\ FKIP-Universitas Kristen Satya Wacana
}

\begin{abstract}
This study aims to describe the increase of critical thinking skills in learning Mathematics of fifth-grade students in SD N Noborejo 01 Argomulya sub-district, Salatiga. This study is a spiral action class study of the Mc. Taggart model which consists of 2 cycles, where each cycle has 4 stages, namely the stages of planning, acting, observing, and reflecting, however at the acting and observing stages were carried out at the same time. The data collection techniques carried out in this study were observation and tests. The instruments used were the observation sheet of teacher and student activities as well as a test sheet for students' critical thinking skills. Data analysis was performed using comparative descriptive analysis, this was done by comparing the pre-cycle, cycle I and cycle II. The researcher determined the success indicator of $80 \%$ of students completing with the Minimum Criteria of Mastery Learning $\geq 70$. The results showed that by applying the Problem Based Learning model students' critical thinking skills in mathematics subjects can be improved, where it was shown that in the first cycle students' critical thinking skills was $58.98 \%$ and in the second cycle, it increased to $97.44 \%$. The number of students who completed the pre-cycle was 15 $(38.5 \%)$ students, where it increased to $22(56.4 \%)$ students in cycle I and increased again to $33(84.6 \%)$ students in cycle II. The research can be said successful because it has reached a success indicator of $80 \%$ of all fifth-grade students who completed the Minimum Criteria of Mastery Learning $\geq 70$. Based on these results, research with Problem Based Learning learning models can improve students' critical thinking skills thus it influences student learning outcomes on the subject of mathematics.
\end{abstract}

Keywords: Problem Based Learning, Critical Thinking Skills, Mathematics

\section{PENDAHULUAN}

Kementerian Pendidikan dan Kebudayaan menegaskan bahwa saat ini seluruh sekolah wajib menerapkan Kurikulum 2013 pada tahun ajaran 2018/2019 (Karsiyem, 2018). Target dari implementasi Kurkulum 2013 adalah perubahan pendidikan karakter yang terintegrasi di sekolah, baik intrakurikuler, ekstrakurikuler maupun kokurikuler. Permendikbud No. 22 tahun 2013 menyatakan bahwa salah satu pola perubahan kurikulum 2013 adalah pola pembelajaran ilmu pengetahuan tunggal (monodiscipline) 
yang berubah menjadi pembelajaran ilmu pengetahuan jamak (multidicipline) dengan menggunakan pendekatan ilmiah (scientific), tematik terpadu (tematik antar matapelajaran), dan tematik (dalam suatu mata pelajaran), perlu diterapkan dengan pembelajaran berbasis penyingkapan/penelitian (discovery/inquiry learning) atau berbasis pemecahan masalah atau proyek.

Proses pembelajaran yang diberikan mulai kelas I hingga kelas VI SD menggunakan model pembelajaran tematik integratif. Pembelajaran tematik terpadu yaitu suatu model pembelajaran yang mengintegrasikan beberapa mata pelajaran dalam satu kesatuan yang terikat oleh tema (Utari, Degeng, \& Akbar, 2016). Pembelajaran tematik merupakan suatu usaha memadukan pengetahuan secara komprehensif dan terintegrasi. Namun, dalam kurikulum 2013 ini mata pelajaran matematika berdiri sendiri terlepas dari pembelajaran tematik.

Matematika merupakan salah satu mata pelajaran yang berperan penting dalam mengembangkan intelektual dan proses berpikir siswa. Hal ini dikarenakan matematika merupakan cabang ilmu yang menerapkan logika yang benar dalam proses berpikir dan menawarkan penalaran logis dalam menguji suatu fenomena atau persoalan (Pramudita \& Anugraheni, 2017). Untuk mencapai tujuan ini maka pembelajaran matematika harus memberi kesempatan siswa memecahkan masalah kontektual yang melibatkan kemampuan berpikir kritis maupunn berpikir kreatif (Wahyudi, Wahluya, Rochmad \& Suyitno, 2018). Hal ini belum semua terwujud, masih banyak pembelajaran yang masih menekankan pada penyelesaian materi dan tidak melibatkan kemampuan berpikir tingkat tinggi (Suarma \& Kusumah, 2016; Wahyudi, Waluya, \& Rochmad, 2018).

Berdasarkan hasil observasi diketahui bahwa hasil belajar matematika siswa kelas V SD Noborejo 01 masih banyak yang belum mencapai KKM $\leq 70$, diketahui bahwa siswa cenderung lebih pasif saat pembelajaran matematika. Selain itu siswa dalam mengerjakan soal matematika masih cenderung menghafal rumus. Kemampuan yang diperlukan dalam matematika tidak hanya sebatas pada kemampuan menghafal saja, tetapi juga diperlukan kemampuan memahami dan menghubungkan fakta. Belajar dengan lebih banyak menghafal tidak terlalu banyak menuntut aktivitas siswa untuk berpikir sehingga kebiasaan tersebut membuat siswa bersikap pasif. Upaya guru yang telah dilakukan yaitu dengan memberi soal-soal latihan, namun hal itu belum dapat meningkatkan kemampuan berpikir kritis siswa dengan maksimal. Oleh karena itu, peneliti berkolaborasi dengan guru kelas $\mathrm{V}$ melakukan penelitian tindakan kelas untuk meningkatkan kemampuan berpikir kritis siswa.

Kemampuan berpikir kritis merupakan kemampuan berpikir tingkat tinggi dalam memecahkan masalah secara rasional. Kemampuan berpikir kritis memiliki 4 tahap dalam memecahkan masalah, yaitu tahap klarifikasi, tahap assesmen, inferensi, dan strategi. Tahap klarifikasi yaitu tahap siswa menyatakan masalah dan menganalisis pengertian dari masalah, pada tahap ini siswa dapat menemukan informasi yang diketahui dalam soal secara tepat. Tahap assesmen yaitu tahap siswa mengajukan informasi yang relevan dan menentukan kriteria penilaian, pada tahap ini siswa dapat merumuskan pertanyaan yang diminta dari soal. Tahap inferensi atau penyimpulan, tahap siswa membuat kesimpulan dan menegeralisasi, pada tahap ini siswa dapat menentukan ide/konsep yang akan 
digunakan dalam menyelesaikan soal. Tahap strategi yaitu tahap siswa mengambil tindakan dan menjelaskan tindakan, tahap ini siswa dapat menjelaskan langkah penyelesaian soal yang sudah ditemukan dengan tepat (Faiz, 2012; Suparno \& Irianto, 2014; Tuanakotta, 2011; Jacob and Sam, 2008)

Secara umum tingkat kemampuan berpikir kritis siswa masih tergolong rendah, hal ini dikarenakan salah satunya dengan penerapan model pembelajaran yang kurang inovatif dan pembelajaran yang tidak menuntut siswa untuk memecahkan suatu masalah dalam pembelajaran serta pembelajaran yang tidak berpusat pada siswa. Salah satu model yang dapat diterapkan untuk pembelajaran yang berpusat pada siswa dan dapat berlatih dalam memecahkan suatu masalah salah satunya yaitu menggunakan model kooperatif. Model kooperatif yang dapat meningkatkan kemampuan berikir kritis yaitu model Problem Based Learning.

Model Problem Based Learning merupakan model pembelajaran yang menggunakan masalah nyata kehidupan sehari-hari sebagai dasar untuk memperoleh pengetahuan dan konsep dalam mengembangkan kemampuan memecahkan masalah melalui berpikir tingkat tinggi (Rahmadani \& Anugraheni, 2017; Fakhriyah, 2014; Slameto, 2015; Indarwati, Wahyudi \& Ratu, 2014). Dalam hal ini model Problem Based Learning melatih siswa terbiasa memecahkan masalah dalam kehidupan sehari-hari dengan tingkat berpikir secara mendalam.

Model Problem Based Learning melibatkan siswa berperan aktif serta kritis dalam pembelajaran, hal ini dikarenakan siswa dapat memecahkan masalah melalui tahap memahami, menganalisi, merumuskan dan menemukan penyelesaian masalah dengan tepat. Secara praktis terdapat manfaat bagi siswa, yaitu :

a. Penerapan Problem Based Learning diharapkan dapat memberikan pengalaman kepada siswa dalam memecahkan masalah dikehidupan sehari-hari. Serta dapat melatih siswa dalam bekerja secara kelompok, bagi,

b. Penerapan Problem Based Learning diharapkan dapat menjadi alternatif model pembelajaran yang bisa digunakan oleh guru dalam proses pembelajaran matematika. Selain itu dapat memberikan gambaran kepada guru mengenai pelaksanaan model Problem Based Learning untuk diterapkan dalam proses pembelajaran matematika di kelas yang berkaitan dengan kemampuan berpikir kritis siswa, dan bagi sekolah

c. Memberikan referensi kepada pihak sekolah tentang efektivitas penerapan model Problem Based Learning sehingga dapat diterapkan dalam proses pembelajaran di kelas khususnya dalam kemampuan berpikir kritis siswa sehingga dapat meningkatkan mutu dan kualitas sekolah.

\section{METODE PENELITIAN}

Penelitian ini merupakan penelitian tindakan kelas (PTK). Penelitian tindakan kelas adalah kegiatan penelitian ilmiah yang dilakukan oleh tenaga pendidik atau guru yang dilakukan secara sengaja di dalam kelas dan bertujuan untuk meningkatkan atau memperbaiki proses pembelajaran, mengacu pada model spiral dari C. Kemmis dan MC. Taggart. Rencana tindakan yang dilakukan yaitu melalui 2 siklus. Tiap siklus pada penelitian ini terdiri dari empat komponen, yaitu perencanaan (planning), tindakan 
Penerapan Model Problem Based Learning Untuk Meningkatkan Kemampuan Berpikir Kritis ...

(acting), pengamatan (observing), dan refleksi (reflecting). Tetapi pada komponen acting dan observing dilakukan dengan waktu bersamaan.

Jenis analisis data yang digunakan dalam penelitian ini menggunakan data kualitatif dan data kuantitatif. Dimana data kualitatif merupakan data yang diambil dari hasil pengamatan langsung menggunakan lembar observasi aktivitas siswa dan guru dalam proses belajar mengajar dengan menerapkan model Problem Based Learning. Data kuantitatif merupakan data yang diambil dari hasil tes evaluasi kemampuan berpikir kritis siswa. Data dianalisis menggunakan analisis deskriptif komparatif. Dimana teknik ini dilakukan dengan membandingkan hasil penelitian antar siklus sebanyak 2 kali setiap siklus terdapat indikator keberhasilan indikator kinerja mencapai ketuntasan $80 \%$ dari jumlah keseluruhan kegiatan belajar mengajar menggunakan model Problem Based Learning dan hasil tes evaluasi siswa mencapai nilai standar ketuntasan $\geq 70$, setiap siklusnya terdiri dari satu pertemuan dengan alokasi waktu $2 \times 35$ menit. Pengamatan dilakukan sesuai dengan pedoman RPP yang telah dibuat oleh peneliti yaitu pada mata pelajaran matematika semester 2 tahun pelajaran 2018/2019. Penelitian ini dilakukan di SD Negeri Noborejo 01 kecamatan Argomulyo kota Salatiga. Penelitian ini mengambil mata pelajaran Matematika dengan materi bangun ruang dengan menggunakan model Problem Based Learning. Penelitian ini berfokus pada siswa kelas V yang terdiri dari 39 siswa, 20 siswa perempuan dan 19 siswa laki-laki.

Teknik pengumpulan data yang digunakan pada penelitian tindakan kelas ini yaitu observasi dan tes. Teknik observasi dalam penelitian ini yaitu digunakan untuk mengamati aktivitas siswa dan guru dalam proses belajar mengajar penerapan model Problem Based Learning. Tes dalam penelitian ini yaitu menggunakan soal uraian yang diberikan kepada siswa untuk mengukur kemampuan berpikir kritis siswa.

Instrumen pengumpulan data yang digunakan yaitu soal tes tertulis sebanyak 8 soal serta lembar observasi aktivitas guru dan siswa. Soal tes yang diberikan kepada siswa sebelumnya diuji validitas terlebih dahulu dengan menggunakan SPSS 16 For Windows, dan telah mendapat persetujuan dari dosen pembimbing dan guru kelas V SD Noborejo 01 Salatiga. Berdasarkan data yang terkumpul dianalisis menggunakan data kualitatif dan data kuantitatif. Data observasi yang telah diperoleh dianalisis menggunakan deskriptif kualitatif dengan membandingkan tahap-tahap pembelajaran berdasarkan tahapan sintaks model Problem Based Learning. Data nilai tes dianalisis menggunakan deskriptif kuantitatif dengan membandingkan nilai pra siklus, siklus I dan siklus II.

\section{HASIL PENELITIAN DAN PEMBAHASAN}

Hasil penelitian ini berkaitan dengan kemampuan berpikir kritis pembelajaran matematika siswa kelas V SDN Noborejo 01 Kecamatan Argomulyo Kota Salatiga. Penelitian ini dianalisis menggunakan analisis deskriptif komparatif yaitu dengan membandingkan hasil belajar siswa antar siklus. Pelaksanaan penelitian setiap siklusnya akan dipaparkan secara bersamaan sehingga dapat terlihat perbandingan perkembangan kemampuan berpikir kritis siswa setiap siklusnya. 
Pada kondisi awal sebelum diadakan penelitian, guru belum menjelaskan tahapan berpikir kritis secara rinci, sehingga siswa dalam mengerjakan soal-soal cenderung menghafal rumus dan tidak memperhatikan cara pengerjakan soal dengan tahapan berpikir kritis dengan tepat. Oleh karena itu pada kondisi awal menunjukkan bahwa kegiatan pembelajaran belum dapat dikatakan maksimal, siswa masih pasif dan dalam menyelesaikan soal matematika sehingga berdampak pada kemampuan berpikir kritis siswa. Adapun solusi dari permasalahan ini yaitu dengan menerapkan model Problem Based Learning.

Kemampuan berpikir siswa pada siklus I belum dapat dikatakan maksimal, dikarenakan sebagian siswa belum dapat menyelesaikan soal dengan tahapan-tahapan berpikir kritis dengan tepat. Tetapi, keadaan siswa pada siklus I sudah mengalami peningkatan dibanding dengan keadan siswa sebelum diadakanya penelitian tindakan kelas. Pada siklus I siswa sudah mulai aktif dalam pembelajaran walaupun belum sepenuhnya. Beberapa siswa masih suka berbicara sendiri. Pada kegiatan diskusi beberapa siswa masih mengandalkan anggota kelompok dalam menyelesaikan masalah. Hal ini dikarenakan siswa yang belum terbiasa dengan model Problem Based Learning. Pengamatan pembelajaran pada siklus I, peneliti belum sepenuhnya melaksanakan tindakan yang sudah direncanakan. Peneliti belum maksimal pada pembagian waktu diskusi kelompok. Peneliti belum maksimal dalam menguasai kelas sehingga beberapa siswa belum fokus pada pembelajaran. Peneliti dan siswa harus bekerjasama lebih baik lagi pada pembelajaran siklus II agar pelaksanaan model Problem Based Learning dapat berjalan sesuai rencana dan mendapat hasil yang baik.

Keadaan siswa pada siklus II meningkat lebih baik dibanding pada siklus I. Kegiatan pembelajaran berjalan dengan baik dan maksimal, terlihat dari hasil belajar siswa yang meningkat serta siswa sudah menerapkan tahapan-tahapan berpikir kritis dalam mengerjakan soal matematika dengan tepat. Siswa terlihat aktif dan senang dalam kegiatan pembelajaran. Kerja sama siswa saat kegiatan diskusi kelompok lebih maksimal sehingga tidak hanya mengandalkan anggota kelompoknya. Kegiatan diskusi berjalan lancar sesuai batasan waktu yang diberikan. Peneliti menyadari kekurangan - kekurangan pada siklus I sehingga pada siklus II peneliti lebih maksimal dalam kegiatan pembelajaran. Peneliti meningkatkan pengusaan kelas dengan baik sehingga semua siswa sudah fokus pada kegiatan pembelajaran. Secara umum kegiatan pembelajaran pada siklus II ini sudah berjalan dengan maksimal. Semua kegiatan inti sudah dilaksanakan sesuai rencana.

Kemampuan berpikir kritis terdapat 4 tahapan. Tahap pertama klarifikasi, indikator berpikir kritis pada tahap ini yaitu siswa dapat menemukan informasi yang diketahui dalam soal dengan tepat. Tahap kedua Assesmen, indikator berpikir kritis pada tahap ini yaitu siswa dapat merumuskan pertanyaan yang diminta dari soal dengan tepat. Tahap ketiga penyimpulan, indikator berpikir kritis pada tahap ini yaitu siswa dapat menentukan ide/konsep yang akan digunakan dalam menyelesaikan soal dengan tepat. Tahap keempat strategi, indikator berpikir kritis pada tahap ini yaitu siswa dapat menjelaskan langkah penyelesaian soal yang sudah ditemukan dengan tepat. Setiap tahapan berpikir kritis memiliki skor maksimal 4. siswa dikatakan sangat kritis apabila 
Penerapan Model Problem Based Learning Untuk Meningkatkan Kemampuan Berpikir Kritis ...

mendapat nilai antara 84-100 dari 8 soal, dikatakan kritis apabila mendapat nilai antara 72-83,9 dari 8 soal, dikatakan cukup kritis apabila mendapat nilai 60-71,9 dari 8 soal, dikatan kurang kritis apabila mendapat nilai antara 48-61,9 dari 8 soal, dikatakan tidak kritis apabila mendapat nilai $0-47,9$ dari 8 soal. Dengan acuan penilain sebagai berikut :

$$
\text { Nilai }=\frac{\text { skor yang diperoleh }}{\text { skor maksimak }} \times 100
$$

Adapun peningkatan kemampuan berpikir kritis siswa sebelum dan sesudah pelaksanaan pembelajaran dengan diterapkannya Problem Based Learning dipapakarkan pada tabel 1 Hasil Analisis Kemampuan Berpikir Kritis Siswa Kelas V SDN Noborejo 01 Salatiga, berikut ini.

Tabel 1 Hasil Analisis Kemampuan Berpikir Kritis Siswa Kelas V SDN Noborejo 01 Salatiga

\begin{tabular}{cccccccc}
\hline \multirow{2}{*}{ No } & \multirow{2}{*}{ Kategori } & \multicolumn{2}{c}{ Prasiklus } & \multicolumn{2}{c}{ Siklus I } & \multicolumn{2}{c}{ Siklus II } \\
\cline { 2 - 7 } & & $\mathrm{F}$ & $(\%)$ & $\mathrm{F}$ & $(\%)$ & $\mathrm{F}$ & $(\%)$ \\
\hline 1 & Sangat Kritis & 2 & $5,13 \%$ & 7 & $17,95 \%$ & 17 & $43,59 \%$ \\
\hline 2 & Kritis & 6 & $15,38 \%$ & 14 & $35,90 \%$ & 10 & $25,64 \%$ \\
\hline 3 & Cukup Kritis & 13 & $33,33 \%$ & 2 & $5,13 \%$ & 11 & $28,21 \%$ \\
\hline 4 & Kurang Kritis & 5 & $12,83 \%$ & 6 & $15,38 \%$ & 1 & $2,56 \%$ \\
\hline 5 & Tidak Kritis & 13 & $33,33 \%$ & 10 & $25,64 \%$ & 0 & $0 \%$ \\
\hline & Jumlah & 39 & $100 \%$ & 39 & $100 \%$ & 39 & $100 \%$ \\
\hline
\end{tabular}

Berdasarkan Tabel 1 Hasil Analisis Kemampuan Berpikir Kritis Siswa Kelas V SDN Noborejo 01 Salatiga, dapat dijelaskan bahwa terjadi peningkatan kemampuan berpikir kritis siswa dalam pembelajaran matematika setiap siklusnya dengan penerapan model Problem Based Learning. Terjadi peningkatan pada kategori sangat kritis yaitu dari 5,13 persen menjadi 43,59 persen pada siklus II terjadi peningkatan sebesar 39,46 persen, demikian juga pada kategori kritis yaitu dari 15,38 persen menjadi 25,64 persen pada siklus II terjadi peningkatan sebesar 10,22 persen, dan terjadi penurunan pada kategori cukup kritis sebesar 5,12 persen yaitu dari 33,33 persen menjadi 28,21 persen pada siklus II, demikian juga pada kategori kurang kritis yaitu 12,83 persen menjadi 2,56 persen pada siklus II terjadi penurunan sebesar 10,27 persen, terjadi penurunan pada kategori tidak kritis, dimana pada siklus II tidak ada siswa yang masuk dalam kategori tidak kritis.

Keberhasilan atau kegagalan pada penerapan model Problem Based Learning dalam meningkatkan kemampuan berpikir kritis siswa pada pembelajaran matematika dapat dilihat pada tabel 2 Ketuntasan Hasil Belajar Matematika Siswa Kelas 5 SDN Noborejo 01 Salatiga, berikut ini.

Tabel 2 Ketuntasan Hasil Belajar Matematika Siswa Kelas 5 SDN Noborejo 01 Salatiga

\begin{tabular}{|c|c|c|c|c|c|c|c|}
\hline \multirow{2}{*}{ No } & \multirow{2}{*}{ Nilai } & \multicolumn{2}{|c|}{ Prasiklus } & \multicolumn{2}{|c|}{ Siklus I } & \multicolumn{2}{|c|}{ Siklus II } \\
\hline & & $\mathrm{F}$ & $(\%)$ & $\mathrm{F}$ & $(\%)$ & $\mathrm{F}$ & $(\%)$ \\
\hline 1. & Tuntas & 15 & $38,5 \%$ & 22 & $56,4 \%$ & 33 & $84,6 \%$ \\
\hline 2. & Tidak Tuntas & 24 & $61.5 \%$ & 17 & $43,6 \%$ & 6 & $15,4 \%$ \\
\hline \multicolumn{2}{|c|}{ Rata-rata } & \multicolumn{2}{|c|}{53,92} & \multicolumn{2}{|c|}{65,97} & \multicolumn{2}{|c|}{80,24} \\
\hline \multicolumn{2}{|c|}{ Maksimum } & \multicolumn{2}{|c|}{88} & \multicolumn{2}{|c|}{95,8} & \multicolumn{2}{|c|}{100} \\
\hline \multicolumn{2}{|c|}{ Minimum } & \multicolumn{2}{|c|}{20} & \multicolumn{2}{|c|}{33.3} & \multicolumn{2}{|c|}{51} \\
\hline
\end{tabular}

Dari tabel 2 Ketuntasan Hasil Belajar Matematika Siswa Kelas 5 SDN Noborejo

01 Salatiga dapat dijelaskan bahwa terjadi peningkatan hasil belajar siswa pada tes 
evaluasi kemampuan berpikir kritis setiap siklusnya. ketuntasan hasil belajar siswa pada pra siklus yaitu sebesar 38,5 persen tuntas dan 61,5 persen tidak tuntas, pada siklus II mengalami peningkatan yaitu 56,4 persen siswa tuntas dan 43,6 siswa tidak tuntas, sedangkan pada siklus II siswa mengalami ketuntasan hasil belajar sebesar 84,6 persen. Karena pada siklus II ketuntasan hasil belajar siswa melebihi indikator keberhasilan yaitu 80 persen maka tidak perlu diadakan tindakan siklus berikutnya.

Berdasarkan hasil analisis data maka penerapan model Problem Based Learning pada siswa kelas V SDN Noborejo 01 Kecamatan Argomulya Kota Salatiga dapat meningkatkan kemampuan berpikir kritis siswa sehingga berpengaruh terhadap hasil belajar siswa pada mata pelajaran matematika. Hasil penelitian ini diperkuat dengan penelitian terdahulu. Seperti yang dilakukan oleh Setyaningrum (2018), Susilowati (2018),serta penelitian yang dilakukan oleh Islam (2018) yang menyatakan bahwa dengan penerapan model problem based learning dapat meningkatkan kemampuan berpikir kritis dan hasil belajar siswa kelas 4 SDN Boto 1 .

Hal yang membedakan penelitian ini dengan penelitian sebelumnya yaitu penelitian ini mengukur kemampuan berpikir kritis dalam pembelajaran matematika pada materi bangun ruang dengan menerapkan model Problem Based Learning. Pada penelitian ini tidak hanya pada aspek kognitifi saja yang terlihat, namun aspekk afektif dan psikomotor juga terlihat ikut meningkat. Pada pembelajaran Problem Based Learning ini siswa dituntut dapat bekerja dalam kelompok, sehingga setiap siswa memiliki tanggung jawab untuk mengeluarkan pendapatnya. Dengan penerapan model Problem Based Learning ini dapat menjadi pembelajaran yang bermakna dan berkesan sesuai materi yang telah diberikan kepada siswa kelas V SDN Noborejo 01.

\section{SIMPULAN DAN SARAN}

Berdasarkan hasil penelitian pembahasan diatas dapat disimpulkan bahwa dengan diterapkan model Problem Based Learning dapat meningkatkan kemampuan berpikir kritis siswa kelas V SD N Nobororejo 01 Salatiga dalam mata pelajaran matematika pada materi bangun ruang. Hal ini ditunjukkan, kemampuan berpikir kritis dengan penerapan Problem based learning mengalami peningkatan dari siklus I sebesar 58,98\% dan pada siklus II sebesar 97,4\%. Peningkatan hasil belajar siswa pada siklus I terdapat siswa yang tuntas dengan $\mathrm{KKM} \leq 70$ sebanyak 22 siswa dengan presentase $56,4 \%$ dari 39 siswa. Pada siklus II mengalami peningkatan sebanyak 33 siswa dengan presentase $84,6 \%$ dengan $\mathrm{KKM} \leq 70$ dan indikator kinerja $80 \%$. Selain peningkatan yang diharapkan siswa juga dituntut agar memiliki tanggung jawab untuk mengeluarkan pendapatnya. Selain itu penerapan model Problem Based Learning dapat memenuhi 4 tahap dalam berpikir kritis yaitu tahap klarifikasi, tahap assesmen, inferensi dan strategi. Dengan adanya peningkatan dari keberhasilan model pembelajaran Problem Based Learning dapat menjadi pilihan untuk dapat digunakan dalam proses pembelajaran matematika, sehingga tujuan pembelajaran yang diharapkan dapat tercapai dengan baik.

\section{DAFTAR PUSTAKA}


Penerapan Model Problem Based Learning Untuk Meningkatkan Kemampuan Berpikir Kritis ...

Faiz, F. (2012). Thingking Skill, Pengantar Menuju Berpikir Kritis. Yogyakarta: SUKAPress.

Fakhriyah, F. (2014). Penerapan Model Problem Based Learning Dalam Upaya Mengembangkan Kemampuan Berpikir Kritis Mahasiswa. Jurnal Pendidikan IPA Indonesia, 95-101.

Indarwati, D., Wahyudi, \& Ratu, N. (2014). Peningkatan Kemampuan Pemecahan Masalah Matematika Melalui Penerapan Problem based Learning Untuk Siswa Kelas V SD. Satya Widya, 17-27.

Islam, F. M. (2018). Penerapan Model Problem Based Learning Untuk Meningkatkan Berpikir Kritis Dan Hasil Belajar IPA Dalam Tema 8 kelas 4 SD. Jurnal Mitra Pendidikan, 613-628.

Jacob, S., \& Sam , H. (2008). Measuring Critical Thinking In Problem Solving Through Online Discussion Forums In First Year University Mathematics. Proceedings of the International Multi Conference of Engineera and Computer Scientists, Hongkong.

Karsiyem. (2018). Colaborative Academic Supervision To Improve Instructional Competency In Implementation Curriculum 2013 In Alian District. Social, Humanities, and Education Studies (SHEs): Conference Series, 223-233.

Pramudita, W., \& Anugraheni, I. (2017). Studi Penguasaan Matematika dan Bahasa Inggris Mahasiswa Program Studi Pendidikan Guru Sekolah Dasar (PGSD). Scholaria : Jurnal Pendidikan dan Kebudayaan, 70-82.

Rahmadani, N., \& Anugraheni, I. (2017). Peningkatan Aktivitas Belajar Matematika Melalui Problem Based Learning Bagi Siswa Kelas 4 SD. Scholaria : Jurnal Pendidikan dan Kebudayaan, 241-250.

Setyaningrum, M. (2018). Peningkatan Hasil Belajar Menggunakan Model Problem Based Learning (PBL) Pada Siswa Kelas V SD. JARTIKA: Jurnal Risel Teknologi dan Iovasi Pendidikan, 99-108.

Slameto. (2015). Metodologi Pendidikan \& Inovasi Pendidikan. Salatiga: Satya Wacana University Press.

Suarma, D. M., \& Kusumah, Y. S. (2016). Interaksi antara faktor tkam dan pembelajaran terhadap kemampuan penalaran deduktif matematis mahasiswa calon guru SD beserta kinerjanya. Eduhumaniora: Jurnal pendidikan dasar, 4(1).

Suparno, \& Irianto, D. (2014). The Effect of PBL Method Using The Student' Critical Thinking Skill on The Social Studies Subject. Jurnal Pendidikan Ekonomi dan Bisnis (JPEB), 40-52.

Susilowati, R. (2018). Penerapan Model Problem Based Learning Berbantu Media Audio Untuk Meningkatkan Berpikir Kritis Kelas 4 SD. Jurnal Ilmiah Pendidikan dan Pembelajaran, 57-69.

Tuanakotta, T. (2011). Berpikir Kritis Dalam Auditing. Jakarta: Salemba Empat.

Utari, U., Degeng, I., \& Akbar, S. (2016). Pembelajaran Tematik Berbasis Kearifan Lokal Di Sekolah Dasar Dalam Menghadapi Masyarakat Ekonomi Asean (MEA). Jurnal Teori dan Praksis Pembelajaran IPS, 39-44. 
Undang-undang No. 22 Tahun 2013, Peraturan Menteri Pendidikan dan Kebudayaan

Wahyudi, Waluya, S. B., Rochmad, \& Suyitno, H. (2018). Assimilation and Accommodation Processes in Improving Mathematical Creative Thinking with Scaffolding According to Learning Style. In Journal of Physics: Conference Series(Vol. 1097). Institute of Physics Publishing. https://doi.org/10.1088/17426596/1097/1/012156

Wahyudi \& Waluya, B., Rochmad, \& Suyitno, H. (2018). Mathematical Creative Thinking Ability And Scaffolding Process According With Learning Styles For Pre-Service Teachers. Anatolian Journal of Instruction, 3(1), 39-50. Available at: https://onlinelibrary.wiley.com/doi/abs/10.1111/bjdp.12178. 